\title{
AZ ISKOLATEREMTŐ \\ KINDLER JÓZSEF
}

\begin{abstract}
Az MTA Vezetés- és Szervezéstudományi Bizottsága hagyományt kívánt teremteni, amikor elindította megemlékezéssorozatát tudományterületünk elhunyt nagyjairól (l. Vezetéstudomány, 2008. 2. és 3. szám). Ezt a hagyományt szeretnénk bóvíteni, amikor a köztünk éló, 80. életévét betöltố, kiemelkedố hatású személyiség, Kindler József életútjának méltatásához a Bizottság szerény eszközeivel is hozzá szeretnénk járulni.
\end{abstract}

A Magyar Tudományos Akadémia kupolatermében ünnepélyes körülmények között 2009. december 10-én került sor az MTA VSZB, valamint a Corvinus Egyetem rendezésében Kindler professzor köszöntésére, életmúvének méltatására, az ünnepelt tiszteletére írott kötet bemutatására és átadására. A rendezvény felett Pálinkás József, az MTA elnöke, Mészáros Tamás professzor, a Corvinus Egyetem rektora és Barakonyi Károly professzor, az MTA VSZB elnöke vállalt védnökséget, míg a levezető elnöki tisztet Vida Gábor akadémikus látta el. A Kádár Katalin szerkesztésében megjelent kötet 40 szerzố méltatását, emlékezését tartalmazza, bevezetójét Sólyom László köztársasági elnök úr írta. Az eseményen a szakma kiválóságai, több mint száz fó vett részt.

Kindler József professzor sokoldalúsága közismert. Nem tartozott a „szobatudósok” közé: a gyakorlathoz kötődése, a valós élet tisztelete minden írásában, minden előadásában tükröződött. Ennek magyarázata talán abban rejlik, hogy 33 éves korában, 1962-ben lépett az oktatói pályára, főmérnöki pozícióját cserélve katedrára. Előrelátó módon, éles szemmel mindig észrevette a világ tudományos életében kibontakozó azon tendenciákat, amelyek a közelebbi és a távolabbi jövő kutatói és oktatási feladatait determinálták. Mind a Budapesti Múszaki Egyetemen, mind késóbb a (nevét gyakran változtatni kényszerülő) Közgazdaság-tudományi Egyetemen iskolateremtőként tartják számon és ismerik el munkásságát: 4 olyan iskolát is ismerünk, amelynek létrehozása, kibontakoztatása az ô nevéhez füződik. Ezek ma is múködnek, hajdani tanítványai vezetése alatt.

Milyen oktató, milyen kutató és fóként milyen ember Kindler professzor? Következzenek az ünnepi ülésen elhangzott beszédek, amelyek ezekre a kérdésekre autentikus válaszokat adnak.

\section{Zsolnai László:}

\section{A rendszergondolkodás ethosza}

(Gazdaságetikai Központ, Budapesti Corvinus Egyetem \& Judge Business School, University of Cambridge)

Kindler József kedvelt tudósának, a rendszerlemélet klasszikusának, West E. Churchman-nek egyik nagy erejú gondolata volt az ,ethics of the whole systems”. Írásomban ezt a megközelítést követve bontom ki Kindler rendszergondolkodásának implicit etikai előfeltevéseit és következményeit.

1977-ben jelent meg Kindler József - Papp Ottóval közösen írt - nagy hatású múve, a „Komplex rendszerek vizsgálata" (Kindler J. - Papp O., 1977). Könyvükben a komplex rendszerek összemérésének metodológiai és eljárástani problémáit tárgyalják, máig érvényes szemléletben. Bemutatják az általuk kimunkált KIPAmódszert, amely komplex rendszerek soktényezôs értékelését és összemérését teszi lehetôvé.

Négy fontos elvet emelek ki a KIPA-módszertanból, amelyek etikai üzenetét és jelentőségét elemzem. Ezek rendre a következók:

(i) az értékelési tényezók teljessége,

(ii) az értékelési tényezők mérése,

(iii) a diszkvalifikáció kérdése,

(iv) az optimális eloony-hátrány kombináció.

\section{Az értékelési tényezók teljessége}

Kindlerék állandóan hangsúlyozzák, hogy komplex rendszerek esetében - mint például a Sukoróra tervezett King's City kaszinóváros - az összes releváns vetületet és ennek megfeleló értékelési tényezôt figyelembe kell venni. Nem elég tehát egy beruházás tốkebehozatali, munkahely-teremtési és turizmusfejlesztési aspektusát 


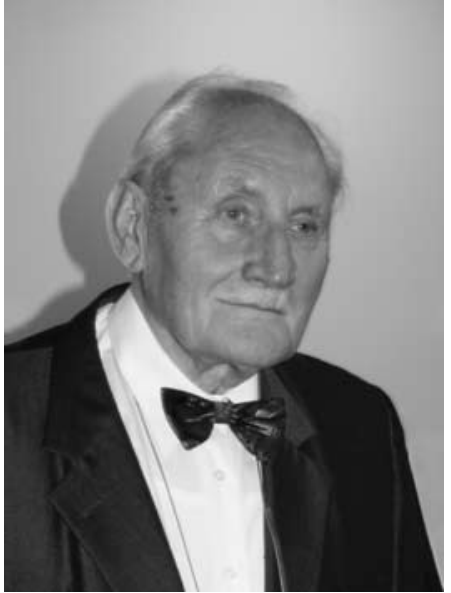

Kindler József (1929. február 9., Budapest): közgazdász, vegyészmérnök.

A MBE Vegyészmérnöki Kar Mg.-i Kémiai és Élelmiszerip. Tagozatán végzett (1954) vegyip. gazdasági mérnöki okl. szerzett (1962), a BME-n doktorált (1965), a közgazdaság-tudományok kandidátusa (1976), doktora (1990), a Dunakeszi Konzervgyár laboratóriumi mérnöke (1954-1956), üzemvezetője (1956-1959), fötechnológusa (1959-1962), az Élelmezésügyi Minisztérium Műszaki Főosztályának főmérnöke (1962), a BME Ip. Üzemgazdaságtan Tanszék egyetemi adjunktusa (1962-1974), egy. docense (1974-1986), az MKKE Vállalat-gazdaságtan Tanszék egy. docense (1986-1989), a BKE Gazdálkodási Kar Környezet gazdaságtani és Technológia Tanszék egy tanára (1989. júl. 1. - 1999. okt. 1.), emeritusz professzora és a PhD-képzés elnöke (1999-től). Az Államigazgatási Egyetem emeritusz professzora. Az Állami Vagyonkezelő Részvénytársaság lgazgatótanácsának tagja (1992-1993).

Matematikai statisztikával, döntéselmélettel, gazdaságetikával, kockázatelmélet-kutatással, illetve ezek környezetvédelmi vonzataival foglalkozott. Jelentős eredményeket ért el a rendszerelméleti döntések elméleti és módszertani kérdéseinek vizsgálata terén, a rendszerelmélet meghonosításának magyarországi kezdeményezője. A magyar élelmiszeriparban elsőként szervezte meg vállalati szinten az eredményes és hatékony matematikai statisztikai minőségellenőrző és szabályozó rendszert, illetve lineáris termelésprogramozást. Részt vett a döntéselmélet KIPA-módszer kidolgozásában.

Az MTA Rendszerkutatási Komplex Bizottság (19751985), Vezetés-és Szervezéstudományi Bizottság (1980-tól), a Művészetelméleti Összehasonlító Munkabizottság tagja. A Nemzetk. Szabványügyi Szervezet Mintavételelméleti Munkabizottsága, a Society for General Systems Research tagja (1984-től).
A Neumann János Számítógéptudományi Társaság Rendszerelméleti Szakosztály, az MTESZ Szervezési és Vezetési Szakosztály, a Magyar Jogász Szövetség Szervezési és Statisztikai Szakosztály vezetőségi tagja. A Magyar Alkotók és Gondolkodók (MAG) alapító tagja.

A Magyar Rádió Rt. Felügyelöbizottságának elnöke (1996-1999), a Magyarok Világszövetsége Százak Tanácsa tagja, a lustitia et Pax Biz. elnökségi tagja.

Eötvös Loránd-díj (1991), Szent-Györgyi Albert-díj (1993), Szilárd Leó Professzori Ösztöndíj (1999), Dunakeszi Díszpolgára (2002).

A Theory and Decision szerkesztőbizottságának tagja, a Magyar Szemle (1997-ig) és az Új Ember c. katolikus hetilap szerkesztőbizottságának tagja.

F. m.: A matematikai programozás lehetőségei az élelmiszeriparban, Baltazár Imrével (Budapest, 1963); Az operációkutatás alapjai, Baltazár Imrével (1963); A korszerű minőség-ellenőrzés egyes kérdései a magyar konzerviparban, Egyetemi doktori értekezések is. (Budapest, 1964); Statisztikai elemzés (Budapest, 1967); Matematikai statisztika, I. (Budapest, 1968); Rendszerelmélet, Vállalati tanulmányok, Vál. Kiss Istvánnal (Budapest, 1969; 2. k. 1971); A rendszerelméletű döntéselmélet egyes kérdései figyelemmel a vezetői döntésekre, Kandidátusi értekezések (Budapest, 1974); Komplex rendszerek vizsgálata, Összemérési módszerek, Papp Ottóval (Budapest,1977); A kreativitást növelő módszerek alkalmazása, Többekkel (Budapest, 1984); Döntéselméleti előfeltevések kritikája, Doktori értekezések (Budapest, 1988); A kockázat döntéselméleti közelítése, Vezetési ismeretek, II. Szeged, 1988); Fejezetek a döntéselméletből, (Budapest, 1991) A stratégiai tervezés módszere és gyakorlata, Papp Ottóval (Budapest, 1992); Etika a gazdaságban, Szerkesztette Zsolnai Lászlóval (Budapest,1993); Döntésmódszertan, Gyombolai Mártonnal (Budapest,1994); Vállalati környezetmenedzsment, Kerekes Sándorral (Budapest, 1997); A 21. század kihívása: A tudásalapú humanista társadalom létrehozása.,Többekkel (Budapest, 2000); fordította: Starr, M. K.: Rendszerelméletű termelésvezetés, termelésszervezés, (Budapest,1973; 2. átd. k., Budapest, 1976); Korten, David C.: Tőkés társaságok világuralma, Ford. (Budapest, 1996).

További információk találhatók a: www.mszi.hu és a www. iskolateremto.hu oldalakon. vizsgálni - mint azt ma sokan teszik -, hanem tekintettel kell lenni a többi aspektusra is. Ilyen például a projekt ökológiai hatása, a helyi közösségek érzékenysége, a kulturális-szimbolikus jelentés és a hosszú távú szocio-ökonómiai következmények.

\section{Az értékelési tényezók mérése}

Kindlerék azt javasolják, hogy minden értékelési tényezốt a neki megfelelö skálán kell mérni. Ez lehet abszolút mérési szintú vagy intervallum szintú vagy ordinális skála. A mai közgazdasági gyakorlat - a költ- 
ség-haszon elemzés szellemében eljárva - pénzben kvantifikálható abszolút mérési szintú adatokkal kíván dolgozni. Ami nem mérhetó pénzben attól vagy eltekintenek, vagy pedig - rendkívül nyakatekert és igen vitatható módszerekkel - kvázi-pézbeni mutatókban fejezik ki. Ez az eljárás etikailag igencsak problematikus (Aldreed, 2009), és skálaelméletileg is elfogadhatatlan, hiszen abszolút mérési szintre transzformál alacsonyabb mérési szintú jelenségeket.

Ezzel szemben a KIPA-módszerben az osztályozó besorolás ötfokozatú skáláit használják, azaz az abszolút és intervallumszintû adatokat transzformálják ordinális szintre. Így válik skálaelméletileg korrektté az egyes értékelési tényezók mérése, és így szolgáltat igazságot a kvalitatív, azaz alacsonyabb mérési szintú, de nem kevésbé fontos aspektusoknak - Amartya Sen új könyvének, a „The Idea of Justice” szellemében (Sen, 2009).

\section{A diszkvalifikáció kérdése}

Kindlerék mindig hangsúlyozzák, hogy nincsenek szuperrendszerek, azaz olyan rendszerek, amelyek minden fontos értékelési tényezóben felülmúlják riválisaikat. Minden komplex rendszernek van valamilyen hátránya valamely másik komplex rendszerrel szemben. Ennek mérésére szolgál a diszkvalifikáció-mutató, ami megmutatja, hogy egy adott rendszer az értékelési tényezók hány százalékában rosszabb, mint a vele összehasonlítandó másik rendszer. Egy kaszinóváros megépítésének nyilvánvalóan vannak jelentôs hátrányai a projekt elmaradásával mint alternatívával szemben.

A KIPA-módszer a hátrányok szintjét maximálja, vagyis megállapítja azt a még elviselhetô értéket, amelynél a jelentkezó hátrányok tolerálhatók. Nem arról van itt szó, hogy - miként a költség-haszon elemzés esetében - az elónyök meghaladják a hátrányokat, hanem arról, hogy lehetnek egy rendszernek olyan jelentôs hátrányai, amelyek egyszerúen megsemmisítik az előnyeit, bármilyen nagyok is legyenek azok.

A Stanford Egyetem zseniális döntéskutatója, a korán elhunyt Amos Tversky „elimination by aspect”-nek nevezte ezt a döntési megfontolást. Egy döntési alternatíva elfogadhatatlan, ha valamelyik tényezóje olyan mértékben negatív, hogy azt a döntéshozó semmilyen kompenzáció fejében sem képes elfogadni. Egy beruházás járhat kulturálisan vagy ökológiailag olyan negatív hatásokkal, hogy „nincs annyi pénz”, ami ezt semmissé tudná tenni.

\section{Az optimális elöny-hátrány kombináció}

Kindlerék szerint az a legjobb rendszer - rendszerek egy adott halmazából -, amely esetében az elónyök és hátrányok optimális kombinációja valósul meg. Ebben az esetben nem lehetséges a rendszer valamely elónyös vonatkozását anélkül növelni, hogy valamely hátránya a többi rendszerhez képest ne növekedjék. A legjobb rendszer ilyen értelemben Pareto-optimális állapotot képvisel. Nagyon más gondolkodás ez, mint a hagyományos közgazdasági megközelítés, amely azt tekinti a legjobb rendszernek, amelynél a pénzben mért előnyök a legjobban meghaladják a pénzben mért hátrányokat.

A sukorói beruházás biztosan nyereségesebb lenne az eredeti helyszínen megvalósítva, mint egy másik - ökológiailag és kulturálisan kevésbé érzékeny - dunántúli helyszínen. Ez azonban nem lehet döntô érv a sukorói táj megerószakolása mellett. Komplex rendszerszemléletben egy társadalom jobban járhat, ha nem valósít meg bizonyos projekteket, vagy nem ott és nem úgy valósítja meg azokat, mint ahol és ahogyan azt a beruházók eltervezték.

A rendszerszemlélet azt sugallja, hogy az életminőséget vagy egyszerúen az emberi életet az szolgálja, ha az alternatívákat teljeskörúen, a maguk értékén véve értékeljük, és döntéseinket - a diszkvalifikált alternatívák kizárása után - a szóba jöhetô alternatívák elônyeinek és a hátrányainak gondos mérlegelése alapján hozzuk meg. Ökológiailag sérülékeny, társadalmilag degradálódott világunkban a rendszerszemlélet alkalmazása a túlélés záloga. Ez az az ethosz, amit Kindler József mindig is képviselt.

\section{Baranyi Árpád: A mindig megújulni kész reneszánsz ember}

(Okleveles közgazdász, PhD, az Altern csoport tagja)

Engedjék meg, hogy Kindler professzor urat a köztünk megszokott módon, Tanár úrként szólítsam meg, hiszen számomra (és sok egykori diákja számára) ô mindig is a „Tanár úr” marad! A Közgazdasági Egyetemról ismerjük egymást, idestova húsz éve. Az egyetemen Kindler professzornak elóbb nappali tagozatos diákja, majd doktoranduszhallgatója, illetve tanszéki munkatársa voltam; késóbb a Korten-könyv egyik fordítójaként, valamint az Altern-csoport alapító tagjaként harcostársává is válhattam, akit megtisztelő barátságába fogadott.

Korán megtanultam: nem egykönnyen lehet ôt zavarba hozni - kivéve, ha szembedicsérik ôt... Kindler professzor azonban minket, diákokat nagyon hamar zavarba tudott hozni. Például azzal, hogy a legtöbb általunk újnak vélt - témáról, amelyet lelkesen elébe vittünk, elkezdett valami történetet, amely ilyenformán kezdődött: „Amikor én ezzel a témával tíz-húsz évvel ezelőtt, az országban elsôként, foglalkoztam..." 
Diákként sokszor volt ilyen élményünk - függetlenül attól, hogy döntéselméletról, gazdaságetikáról, környezetvédelmi témáról, vagy a szubszidiaritás társadalmi szerepérôl volt-e épp szó. Csodálnivaló-e, ha ezek láttán tisztelet ébredt bennünk a professzor iránt? E tiszteletre méltó tudós mégsem maradt megközelíthetetlen a számunkra: nem lett belóle elérhetetlen magasságokban szárnyaló, önnön dicsfényében sütkérező szellemi óriás, hanem közvetlen, baráti, sốt atyai módon gondoskodó pártfogónkká vált. Mielőtt közelebbi kapcsolatba kerültem volna vele, egy szóbeli vizsgán provokatívnak szánt, etikai témájú kérdésére türelmetlenül egy Czakó Gábortól vett idézettel vágtam vissza: „Ha a lét határozza meg a tudatot, akkor az erkölcs vitézkötés a nagy semmin" (az utolsó kifejezés ennél erősebb volt, ugyanis Czakót szó szerint idéztem, ennek az érdeklődốk utánanézhetnek az író múveiben). A Tanár úr azonban nem sértôdött meg, sốt talán ekkor túnhetett föl neki: bizonyos alapkérdésekben hasonlóan gondolkodunk.

Nemcsak tanárunk és támogatónk lett, hanem ennél jóval több: szellemi mesterünk. Szükségünk van ilyen szellemi-erkölcsi útjelzókre, mértékadó személyiségekre. Az emberi élet egyik lényeges célja: a szeretet és igazság egyesítése önmagunkban szüntelen önneveléssel, továbbá mások segítése ugyanezen az úton. Kindler professzortól személyes életpéldáján keresztül tanulhattuk el az igazságkövetésből és a szeretetból fakadó lelkiismereti bátorságot, a társadalmi lelkiismeret és felelôsség belsố hangjának követését, az elmélet és a gyakorlat ötvözésének fontosságát, hiszen mindezek hiányában az elméleti okoskodás - az ô szófordulatával élve - csak ,steril eszmetologatás” marad. Minderról XVI. Benedek pápa Caritas in veritate (Szeretet az igazságban) kezdetú enciklikájában így ír:

Az igazság az a fény, amely értelmet és értéket ad a szeretetnek. Ez a világosság egyszerre az ész és a hit világossága, amely által az értelem eljut a szeretet természetes és természetfeletti igazságához (CIV \#3). ... [Az] igazság iránti bizalom és szeretet nélkül nem létezik társadalmi lelkiismeret és felelósség. (CIV \#5) ... Az igazság nélkül egyfajta empirikus és szkeptikus életszemléletbe zuhanunk, amely képtelen túlemelkedni a gyakorlat szintjén, mivel nem érdekelt az értékeknek az elfogadásában - olykor még ezek jelentésének elfogadásában sem -, amelyek alapján megítélhetné és irányithatná a gyakorlatot. (CIV\#9) ...

Tekintettel a problémák összetett voltára, kézenfekvó, hogy a különbözó tudományágaknak egyfajta rendezett interdiszciplinaritás jegyében kell együtt- múködniük. A szeretet nem zárja ki, sốt megköveteli a tudást, irányítja és belülról átlelkesíti azt. A tudás soha nem csupán intelligencia kérdése. Kétségkivül redukálni lehet számításokra és tapasztalati megfigyelésekre, ám ha bölcsesség kíván lenni, amely az alapelveknek és ezek végsó céljainak fényében el tudja igazítani az embert, akkor a szeretet , sójával” kell megízesíteni. A cselekvés bölcsesség nélkül vak, a bölcsesség szeretet nélkül terméketlen. Akit valódi szeretet lelkesit, azt leleményessé teszi abban, hogy felfedezze a nyomor okait, megtalálja az ellene vívott harc eszközeit, és elszántan le is gyózze a nyomort. (CIV \#30)

Kindler professzor pontosan ezt tette és teszi mind a mai napig. Ezt bizonyítja szerteágazó tudományos és közéleti munkássága, az új iránti fogékonysága, a fontos tudományos-társadalmi kérdésekre rátaláló, csalhatatlan ,szimata”, amelyben az általa sokszor emlegetett „serendipity” jelensége is közrejátszik. Ez az a jelenség, amikor valaki véletlenül belebotlik valami jó, hasznos vagy szép dologba, amelyet egyébként egyáltalán nem is keresett. (A szót, amelyet tóle ismerek, 2004-ben egy brit fordítóiroda a tíz legnehezebben lefordítható angol szó közé sorolta, bár számos más nyelv átvette.) A kifejezés Horace Walpole angol író és politikus szóleleménye, aki erról a következóképpen ír:

Ez akkor történt, amikor egyszer olvastam egy ostoba tündérmesét, amelynek „Serendip három hercege" volt a címe. Öfenségeik utazásaik közben - egyrészt a véletlennek, másrészt éles elméjüknek köszönhetốen - mindig fölfedeztek valamit, amit valojában nem is kerestek. Egyikük például rájött arra, hogy egy a jobb szemére vak teve nemrég végigment ugyanazon az úton - a fú ugyanis csak az út bal oldalán volt lelegelve, bár a fü minôsége ott rosszabb volt, mint az út jobb oldalán. Érti már, mi a serendipity?

E véletlen eszességnek legfigyelemreméltóbb példáját (hiszen látnivaló, hogy oly dolog felfedezése, melyet az ember szándékosan keres, nem tartozik ebbe körbe) az én Lord Shaftsburym szolgáltatta, aki - midón történetesen Clarendon lordkancellárnál vacsorázott - rájött a yorki herceg és Mrs. Hyde házasságára, midón látta azt a tiszteletet, amelyet annak anyja tanúsitott iránta az asztalnál. (Horace Walpole levele Horace Mann-nek, 1754. január 28.)

Amint láthatjuk, a „véletlen eszesség” jelenségéról van szó: amikor valaki „csőre töltött ésszel”, ugrásra készen várja az eseményeket, hogy lecsapjon azokra a témákra, amelyekben megszimatolja az értéket. Louis 
Pasteur szavaival: „A megfigyelés során a szerencse csak a felkészült, éles elmét támogatja." A Tanár úr esetében tehát a szerencse helyett sokkal inkább az éles elme fontosságát kell kiemelnünk. Ilyen jó szimatú, tudatos döntés volt, amikor 1996-ban arra kért: szervezzek össze egy csapatot a Közgázon, amellyel magyarra fordítjuk David C. Korten: Tókés társaságok világuralma címú könyvét. A könyv, amely több mint egy évtizeddel ezelőtt megfogalmazta a - napjainkban hatalmas robajjal összedôlố - neoliberális gazdasági modell erôteljes kritikáját, hamarosan sikerkönyvvé vált Magyarországon. Amikor két évvel késóbb, 1998-ban Kortent meghívtuk Budapestre előadást tartani, a Közgazdasági Egyetem legnagyobb előadója zsúfolásig megtelt érdeklődốkkel, valamint a sajtó képviselóivel.

A Tanár úr számára mindig is fontos volt a közös etikai és szakmai alapokon álló munkatársak közösséggé formálása. A kilencvenes évek végén, látván maga körül azon doktoranduszhallgatókat, akik a neoliberális gazdasági modellel szemben az alternatív, keresztény értékrenden alapuló gazdasági-társadalmi gondolkodást képviselték, e közös gondolkodás folytatására egy szellemi múhely megalakítását javasolta. Így alakítottuk meg 1997-ben a Közgazdasági Egyetemen az Altern-csoportot.

A Tanár úr a szó jó értelmében vett reneszánsz ember, ám szellemi sokoldalúsága mellett még fontosabbak számára életének keresztény alapjai. Mindez a folytonos szellemi fiatalság, a megújulásra való készség mellett olyan életutat eredményez, amely elengedhetetlen az Istenben való folyamatos - és egykor a végsô - újjászületéshez. Isten áldja meg Tanár urat, és segítse továbbra is életútján! Kívánom, hogy a századik születésnapját is ilyen jó kedvvel és lelki-szellemi frissességben ünnepelhesse meg körünkben!

\section{Noszkay Erzsébet: \\ Emberségében erôs és megingathatatlan tudós - példakép}

(Egyetemi m. tanár, a Budapesti Kommunikációs és Üzleti Főiskola tanára)

Kindler professzor mindig előtte járt a kor nagy kihívásainak, azokra igyekezett válaszokat keresni. A maga útját járta és járja, nem motiválta sohasem a divat, sem a tudománypolitikai széljárás! Sôt, mindig bátran felvette a kesztyút, sokszor konfliktusokat is felvállalva, úgy tudósként, mint közéleti emberként egyaránt a „másokért élni tudó ember” legnemesebb példáját adta (csak egyet, a Duna Kört említeném most meg a közismert vállalásaiból), adja ma is embertársai számára.
Minden egyes munkáját átható kristálytiszta logika, rendszerszemlélet, a kultúra és tudás harmonikus egysége jellemez.

Életemben elôször Kopátsy Sándortól hallottam, hogy egy ember értékét a tudása és az általa képviselt erkölcsi értékek szorzata adja. Most, hogy ennyi év után visszatekintek, őszinte érdeklődésem és tiszteletem háttereképp, az említett tényezôben találom meg a választ, hisz Kindler József professzornál mindkét tényezó magas értékeket mutat.

Mestereimnek is köszönhetem, akik mindig azt mondogatták nekem, csakis az igazi értékekre figyeljek, és mindig csak a legjobbaktól tanuljak! Így adta kezembe az első munkahelyemen, az Elektromos Múveknél mesterem-mentorom a következô szavakkal Kindler József Matematikai statisztika címú könyvét: „...most jártam a BME-en! Van ott egy rendkívüli képességú és bátor szellemú oktató, Kindler Józsefnek hívják! Erre a névre emlékezzen és figyeljen rá, tőle mindig érdekes és új irányokról értesülhet majd! Ezt a könyvet azért hoztam, hogy olvassa el és ismerje meg a gondolkodásmódját."

Mondanom sem kell, hogy igencsak elgondolkodtatott az eddig statisztikai ismereteimtől meróben eltéró, újszerú, az akkori idóket tekintve bátor megközelítés!

Ez a fajta kutatói bátorság - bevallom - jobban felkeltette az érdeklődésemet akkor, mint maga a szúkebb értelemben vett szakmai tartalom! Ui. az azokra az idốkre jellemzô - sajátságos (bár a puha diktatúra eszközeivel dolgozó, de azzal nagyon is a kutatói gondolkodást sematizáló és kordák közé szorító) - rendszerben nagy szükségem volt - számomra ideált jelentô - emberségében erôs és megingathatatlan tudós példaképekre! Így kezdtem Kindler József gondolataira és tetteire figyelni! S az idő elôrehaladtával számomra mind inkább ố jelentette azt a fajta erốs karakterú ideált, akit erkölcsi magatartása és a lelki szilárdsága kutatói magatartásában, tetteiben példaként megnyilvánuló tanárként abban segített, hogy tanítványait ne csak önálló véleményalkotásra nevelje, de arra is, hogy erós akarattal a mindennapi életben is meg tudják valósítani a helyesnek megismert nézeteket és erkölcsi elveket.

Kívánom sok fiatal, kezdő kutatónak, hogy - ahogy annak idején számomra - legyen számukra is, ugyanolyan jegenyefa erôsségú, távolról is erôvel ható, sugárzó és segítő példakép Kindler József! Annyit biztosan ígérhetek, hogy ez a választás az egyik legkiválóbb döntésnek fog bizonyulni életük nagy útelágazásainak mentén!

Kindler professzor Úr, nagyra becsült és mélyen tisztelt emberi és tudós ideálom, Isten éltesse sokáig erőben, egészségben! 


\section{Vecsenyi János \\ Kindler József, akinek van mire szerénynek lennie}

(A Budapesti Corvinus Egyetem egyetemi tanára)

Kedves Vendégek! Kedves Kindler József, vagy ahogy a legtöbben hívjuk Kindler Jóska!

Szeretném egy személyes élménysorral indítani a köszöntésemet, felidézve az iskolateremtốk kapcsolódását.

A BME-n 1968-69-ben utolsó éves egyetemistaként ismerkedtem meg a szervezési-vezetési szakma alapjaival Ladó professzor, Máriás professzor előadásaiból és Deli tanár úr gyakorlataiból. Majd az egyetem elvégzése után Ladó professzor hozott össze késóbbi mesteremmel, Szabó Lászlóval, akinél és akivel új életpályára léptem. Ố megkérte Kindler Józsefet, hogy mentorálja egy kicsit az ô fiatal munkatársát, engem, és vezessen be a méréselmélet tudományába, mert ez is hiányzott az én ismereteim közül. Kindler tanár úr nagyon kedvesen elküldött engem, no nem melegebb égtájakra, hanem az Akadémiai Könyvtárba, hogy keressem meg Stevens alapmunkáját és a kapcsolódó cikkeket az ott elérhető folyóiratokban. Merthogy 1970-ben még nem volt se internet, se Google.

Majd elkezdtem gazdasági mérnöki tanulmányaimat és hallgattam újra Ladó professzor, Kocsis tanár úr, Engländer tanár úr, Papp Ottó és társaik elóadásait és persze Kindler József statisztikával és minôséggel foglalkozó előadásait. Túl azon, hogy megismertem a Kendall-féle egyetértési együtthatót és a KIPAmódszert. Ezen túlmenôen egy akkor újdonságnak ható oktatási módszer keretében hallgatótársaimmal projektteamet alkotva kidolgoztuk a Beton és Vasbetonipari Múvek betonelemgyárának minőségszabályozási rendszerét 1972-ben. Az erról készült folyamatábrákat, statisztikai ellenőrző kártyákat, mostani kifejezéssel élve szabályozó kártyákat Szabó László javaslatára megmutattam Mányoky Istvánnak, aki akkor a Finomkerámia Ipari Múvek szervezési osztályvezetóje volt. Neki nagyon tetszett, és megkért, hogy segítsek ezt a módszert bevezetni náluk is. Ezzel indult a FIM-ben a minőségjavítási és selejtcsökkentô program. Ugyancsak Szabó László ajánlására Susánszky János professzor meghívott, hogy tartsak előadásokat a minőségszabályozási módszerekról, az akkor virágzó Borsodi Iskolán.

Így kapcsolódtak össze pályám indulásánál az iskolateremtô mesterek, és kaptam tólük életre szóló útravalót.

Most pedig szeretném megvilágítani, hogy miért adtam azt a címet a köszöntőmnek, hogy Jóskának, akinek van mire szerénynek lennie.
Kezdem azzal, hogy Kindler József szerény ember. Soha nem hivalkodott azzal, hogy ebben vagy abban ô volt az elsố a honban, hogy ô foglalkozott ezzel vagy azzal először e kies hazában. Legfeljebb szerényen megjegyezte, hogy az említett szerzôt, elméletet ő öt, tíz, húsz éve ismeri. Ahogy ezt már az előttem szólók és az emlékkönyv szerzói szinte egytől egyig kiemelik, Kindler Józsefról szinte mindenkinek az jut az eszébe, hogy mit tanult tóle, és ebben az a megkapó, hogy sokan sokfélét. Hiszen Kindler József annyi mindenben volt elsô, volt kezdeményezô. Ố helyettesítette az internetet, ô volt sokunk számára a keresőmotor.

Hadd soroljak fel néhányat, hogy mi minden jött ki az ô keresőjéból:

Tóle kaptam, kaptunk két egymásba fonódó naghatású idézetet. A Goethetôl származót: „fiam fakó minden teória és a lét aranyló fája zöld”, és a másikat, amit Boltzmantól vett át: „,nincs jobb gyakorlat egy jó elméletnél”.

Ő hozta közel hozzánk a már említett Kendall-féle egyetértési együtthatót, és Papp Ottóval közösen ô dolgozta ki a KIPA-módszert, ami a többtényezôs döntésmódszertan első hazai fejlesztése volt.

Ố honosította meg a Stevens-féle meghatározást a mérésról, mely szerint a mérés számok hozzárendelése dolgokhoz, tárgyakhoz vagy eseményekhez, meghatározott szabályok szerint. Most már tudjuk, hogy a számokkal mégse lehet akármit tenni, még kevésbé akármilyen következtetést levonni.

Ô ismertetett meg minket Bouldinggal, Churchmann-nal és a rendszerelmélet és -gyakorlat további nagyjaival, hogy tudjuk, hogy minden mindennel öszszefügg.

Ő toborozta össze Kiss Istvánnal azokat a hazai szakembereket, akik a rendszergondolat apostolai lettek a 70-es évek elején. Közéjük tartozott Hajnal Albert, Nemény Vilmos, Hankiss Elemér, Pléh Csaba, Horányi Özséb, Máriás Antal, Kovács Sándor és mások.

Ő mutatta be Herbert Simont és a korlátozott racionalitás gondolatát, majd a Martin Kenneth Star-féle rendszerszemléletú termelésirányítást.

Beszélt a rövidülő távlatokról, no meg a túzok és a veréb viszonyáról. Elóbb lett dühös a multikra, mint mások, és hívta ehhez tanúként David Kortent, akivel és Jóskával e tekintetben nem mindenben értek egyet.

Ó hívta fel a figyelmünket a Névleges Csoport Módszerre, és mi szinte mindent szögnek néztünk, hogy ezzel kalapáljuk be.

Mindez csak egy rövid lista abból a széles repertoárból, amit Jóska kezdeményezett, és itt még nem említettem a környezetvédelmet, aggodalmát az erdészet jövőjéról, a Duna Kört, az üzleti etikát, a tudományelméletet. 
Nem említettem a bokszot sem. Pedig kellett volna, bár a bokszot mégsem ô vezette be Papp László hazájában, de lelkes amatőrként igyekezett itt is megállni a helyét. Talán ezért, talán a folyamatos újdonságkeresésért maradt ilyen friss és egészséges.

Kedves Jóska!

Maradj továbbra is ilyen friss és egészséges.

Legyél továbbra is szerény. Hiszen van mire.

\section{Zoltayné Paprika Zita: \\ A magyarországi döntéselmélet megalapozója}

(A Budapesti Corvinus Egyetem tanszékvezető docense)

Talán nem meglepő, hogy Kindler tanár úr méltatásához én a döntéselmélet szemszögéből szeretnék csatlakozni. 1991-ben a „Fejezetek a döntéselméletból” címú könyv előszavában a Tanár úr azt írta, hogy „A döntéselmélet és döntésmódszertan a hazai felsốoktatás szerkezetében csak szórványosan jelent meg, talán a posztgraduális gazdasági mérnök képzés kivételével, s leginkább a hazai vezetốképzés és továbbképzés különféle szakterületei ismerték fel jelentôségét, s illesztették oktatását tanfolyami tantervekbe.” Örömmel jelentem, hogy azóta sokat változott a világ: mostanra egyedül a Corvinus Egyetemen 38 olyan kurzus kerül meghirdetésre évente, melynek címében a döntés szó szerepel, és ezt egészíti ki 6 további angol nyelvú kurzus, amely címében megjelenik a decision szó. Ahogy mondani szokás: mindez nem jöhetett volna létre Kindler tanár úr nélkül! A döntéselmélet címú tárgy kereteinek kitalálása, graduális szintre történô pozicionálása idôtállónak bizonyult, ami Kindler tanár úr - a mai nap folyamán már sokszor hivatkozott - tudományos/akadémiai szimatát dicséri. Mindig is lenyúgözött bennünket az, ahogy az új témákat, kutatási lehetőségeket felismerte és elindította.

Az elsố magyar nyelvú döntéselmélet-könyv - melyet 1991-ben ő jegyzett - múhelymunkájára visszagondolva érdemes megemlíteni, hogy fel sem merült, hogy valamelyik külföldi, pl. amerikai könyvet fordítsuk le magyarra. Fontos szempont volt, hogy a témák gazdag tárházából azokat választottuk ki, amelyekhez kutatási eredményeket, tapasztalatokat tudtunk kapcsolni. A kötet nagy eróssége a fejezetek gondos megválogatása mellett a Függelékben megjelenő két könyvrészlet volt, Simontól és Marchtól, melyeket egy angol-magyar szószedet egészített ki, amely számos döntéselméleti kifejezés magyar megfelelójének első fellelési helye. A másik mérföldkő a magyarországi döntéselméleti irodalomban a Tanár úr által válogatott és Pápai Zoltán és Nagy Péter által szerkesztett Döntéselméleti szöveggyújtemény volt, amely az internet előtti idôszakban a legfontosabb döntéselméleti irodalmakat elsốként juttatta el az érdeklódő hallgatókhoz, olvasókhoz.

Az elsố magyarul megjelent döntéselméleti szakkönyv és szöveggyújjtemény visszatükrözi Kindler tanár úr kézjegyét, szakmai jártasságát a tudományok és a múvészetek terén egyaránt. Így jelenhetett meg a forrásmunkák között a Mediterrán mondák és mítoszok 1973-as kiadása mellett a Pszichológiai alapfogalmak címú könyv, illetve a Biblia. Természetes volt számunkra, hogy amikor 2002-ben megírtuk az új Döntéselmélet-könyvet elsóként a Tanár úrnak adtuk át, a véleményét, kritikáját kérve.

A reneszánsz, a humanizmus és a döntések szoros kapcsolatot mutatnak. Petrarca alapította meg az új tudásszerzési módszert, a humanizmust, ami az embert az önálló döntés és gondolkodás képességével rendelkezô racionális és érzó lénynek tekinti. A reneszánsz embert mindenekelőtt a maga univerzális valóságában kell vizsgálnunk, mivel a reneszánsz ember univerzális ember, ellentétben korunk redukált emberével. Kindler tanár úr méltatásai jó mutatták sokoldalúságát, több tudományterületen végzett úttörô munkáját és korszakot nyitó tevékenységeit.

A francia eredetú reneszánsz (renaissance) szó újjászületést jelent. Ez elsôsorban az ókori klasszikus szövegek, ismeretek és ezek hasznosításának múvészeti és tudományos újrafelfedezésére utal. Másodsorban ezeknek a szellemi tevékenységeknek az eredményeként az európai kulturális élet általánosságban vett újjászületését is jelöli. A reneszánsz világkép részben a humanizmuson, vagyis az emberközpontúságon, részben pedig a természetben megfigyelhetố változások magyarázatának igényén alapult. Az emberközpontúság és a természet megértésének igénye, a természetért érzett felelősség a Tanár úr munkásságát is végigkíséri.

Éppen ezért nem meglepó, hogy amikor a Googleba a következô szavakat írjuk be: Kindler József, a reneszánsz ember 0,23 másodperc alatt 106 tétel jelenik meg. Ugrásszerú emelkedést találunk a sebességben és a találatok számában egyaránt, hiszen pár héttel korábban 0,33 másodperc alatt „csak” 86 találatot kaptunk ugyanerre a keresésre. Természetesen első helyen „Az iskolateremtô Kindler József professzor" címú kötet jelenik meg, s annak is a nyitó interjúja, Kindler József, a reneszánsz ember címmel.

A reneszánsz ember legnagyobb élménye a saját világa formálása. A reneszánsz gondolkodás jellemzói a felfokozott életöröm, igény a politikai és szellemi pezsgés iránt. Ehhez kívánok további sok sikert és jó egészséget a Tanár úrnak. 
Terjedelmi okokból nem ismertethetjük az elhangzott hozzászólásokat, meg kell említenünk Papp Ottó, Véry Zoltán („A Kindler-archívum”), Ruzsányi Tivadar („Módszertani segítség a Nemzeti Klímaváltozási Stratégiához”), Szíjjártó István („Egy szeretetet sugárzó bölcs ember a Százak Tanácsában"), Erdôsi Gyula (,Az iskolateremtók emléklevele”) nevét, amelyek tovább színesítették a Kindler Józsefról festett portrét.

Befejezésül álljon itt a kiváló, nemzetközi nagyság - a YES! magazin bizottsági elnöke, a When Corporations Rule the World, The Great Turning from Empire to Earth Community és az Agenda for a New Economy: From Phantom Wealth to Real Wealth szerzójének az ünnepléshez intézett levele (amely hangüzenet formájában is elhangzott).

Tisztelt Kindler professzor!

Mindenekelőtt fogadja szívből jövő jókívánságaimat 80. születésnapja alkalmából. Az Ön személyében napjaink egyik nagyszerú tudósát tisztelhetjük, aki képes ösztönzést adni hallgatóinak és szárnyai alá vett diákjainak egyaránt. Végtelenül hálás vagyok a When Corporations Rule the World (Tókés társaságok világuralma) címú könyv magyar fordításának korrektúrájáért, valamint szeretném megköszönni Önnek és munkatársainak, hogy a reklámkampány során tett erőfeszítéseik nyomán a könyv magyarországi bestseller lett.

A könyvbemutató alkalmából Magyarországon tett látogatásom életem egyik legemlékezetesebb élménye volt. Magyarország gazdasága akkoriban már elindult a kapitalizmushoz vezetô úton, Ön pedig mindent megtett azért, hogy ráébressze a nemzetet a lehetséges társadalmi és környezeti következményekre, amelyek akkor leselkednek az országra, ha nyitottá válik a kizsákmányoló politikát folytató nemzetközi vállalatok által uralt kapitalizmus romboló formáira.

Minden jót kívánok ehhez életének eme kivételes alkalmához.

Szívélyes üdvözlettel:

Dr. David Korten

A zárófogadáson Kerekes Sándor méltatta meleg, személyes hangú szavakkal Kindler professzor érdemeit.

Barakonyi Károly,

az MTA Vezetés- és

Szervezéstudományi Bizottságának elnöke 